\title{
Immune Response Study to Live Infectious Bursal Disease Vaccines in Broiler Chickens
}

\author{
Pooja Kundu ${ }^{\text {** }}$, G. Narang ${ }^{2}$, Rajesh Chhabra ${ }^{3}$, Sushma Kajal ${ }^{2}$, \\ N.K. Mahajan ${ }^{1}$ and Naresh Kakkar ${ }^{4}$
}

${ }^{1}$ Department of Veterinary Public Health and Epidemiology, College of Veterinary Sciences, Lala Lajpat Rai University of Veterinary and Animal Sciences, Hisar- 125004, Haryana, India

${ }^{2}$ Department of Veterinary Pathology, College of Veterinary Sciences, Lala Lajpat Rai

University of Veterinary and Animal Sciences, Hisar- 125004, Haryana, India

${ }^{3}$ College Central Lab, College of Veterinary Sciences, Lala Lajpat Rai University of Veterinary and Animal Sciences, Hisar- 125004, Haryana, India

${ }^{4}$ Department of Veterinary Microbiology, College of Veterinary Sciences, Lala Lajpat Rai

University of Veterinary and Animal Sciences, Hisar- 125004, Haryana, India

*Corresponding author

\begin{tabular}{|c|c|}
\hline \multicolumn{2}{|r|}{ A B S T R A C T } \\
\hline & \multirow{6}{*}{$\begin{array}{l}\text { Vaccination plays an important role in the successful control of infectious bursal disease } \\
\text { (IBD). Despite the regular use of IBD vaccines, the disease prevails in Haryana state and } \\
\text { affects the flocks of different age groups. Control of IBD poses one of the most } \\
\text { challenging tasks in the poultry health management. To evaluate the vaccine immune } \\
\text { response of IBD vaccines, an experimental study was conducted using two commercial } \\
\text { intermediate plus vaccines P and Q. The level of maternal antibodies (MAbs) ranged from } \\
6834.6 \text { to } 9925.60 \text { in day old chicks. In experimental birds the age of vaccination was } \\
\text { calculated on the basis of MAb titres and it came to be } 17 \text { days of age. The mean maternal } \\
\text { antibody titre of chicks at } 1,7 \text { and } 14 \text { day age was } 7874.21,2449.4 \text { and } 1089.9 \text {. The mean } \\
\text { MAb titre showed a steady decline in the titre from day old age to } 14^{\text {th }} \text { day of age. Vaccine } \\
\text { P showed static increase in ELISA antibody titres from } 7 \text { DPV however vaccine Q showed } \\
\text { quite higher level of antibody titres on } 7 \text { DPV itself which remain protective till the end of } \\
\text { experiment in both. CD4+ cells increased at } 7 \text { DPV, decreased at } 14 \text { and } 21 \text { DPV, again } \\
\text { increased at } 28 \text { DPV. CD8+ cells increased at } 7 \text { DPV, decreased at } 14 \text { DPV, again } \\
\text { increased at } 21 \text { and } 28 \text { DPV. This decrease in CD4+ and CD8+ cells at } 14 \text { and } 21 \text { DPV is } \\
\text { probably due immunosuppressive effect of IBD vaccines. Both vaccines P and Q provided } \\
\text { protective immunity from } 7 \text { DPV till the end of experiment but with immunosuppressive } \\
\text { effect of IBD vaccines. Further studies are required to see the variation in protection and to } \\
\text { monitor immunosuppression induced by different vaccine strain available in our area. }\end{array}$} \\
\hline Keywords & \\
\hline $\begin{array}{l}\text { Immune response, } \\
\text { Vaccination, } \\
\text { Antibodies. }\end{array}$ & \\
\hline Article Info & \\
\hline $\begin{array}{l}\text { Accepted: } \\
19 \text { October } 2017 \\
\text { Available Online: } \\
10 \text { December } 2017\end{array}$ & \\
\hline & \\
\hline
\end{tabular}

\section{Introduction}

Infectious bursal disease (IBD) commonly known as Gumboro disease is a disease of global economic importance (Pitcovski et al., 2003). Cosgrove initially described the disease as "avian nephrosis" on account of the tubular degenerative lesions found in the kidneys of infected broiler chickens. The syndrome adopted the name "Gumboro 
disease" since the first outbreak occurred in and around the area of Gumboro, Delaware, USA (Cosgrove, 1962). The disease is characterized by the destruction of the lymphoid cells in the bursa of Fabricius as the virus replicates in differentiating Blymphocytes (Cheville, 1967). But due to specific pathognomonic lesions produced in bursa of Fabricius, it was later termed as infectious bursal disease (IBD) (Hitchner, 1970). The disease is produced in broiler chicks between 3-6 weeks of age and immunosuppression is the main consequence in infected chicks (Kibenge et al., 1988).

The infectious bursal disease virus (IBDV) is classified in the Avibirnavirus genus of the family Birnaviridae (He et al., 2012). Two distinct serotypes of IBDV designated as serotypes 1 and 2 , have been identified. Serotype-1 viruses were differing in virulence to chickens, whereas serotype-2 viruses, initially isolated from turkeys, were avirulent (Ismail et al., 1988). Based on virulence and antigenicity, serotype-1 viruses had been classified as attenuated, intermediate virulent, classical virulent, variant and very virulent (Van den Berg, 2000). Variant IBDVs do not cause mortality, whereas the classical strains cause up to $20 \%$ mortality (Muller et al., 2003). Very virulent IBDV (vvIBDV) causes mortality exceeding $50 \%$ in susceptible chickens (Chettle et al., 1989; Van den Berg et al., 1991; Muller et al., 2003).

Infectious bursal disease virus is highly resistant to adverse environmental conditions. It is more resistant to heat and ultraviolet light than reovirus and also resistant to ether and chloroform. Once infected with IBDV, chickens are capable of shedding the virus in faeces for as long as 16 days (Winterfield et al., 1972). Benton et al., (1967) reported that poultry houses which previously harbored infected flocks remained infective for at least 122 days and fomites (water, feed, droppings) contaminated with IBDV contribute to viral dissemination.

In India, the disease was first reported by Mohanty et al., (1971). Asrani et al., (1993) conducted a survey in Gurgaon region of Haryana in chicken flocks experiencing heavy mortality. These authors revealed that all unvaccinated commercial broiler flocks with or without concurrent infections, manifested appreciably high ELISA antibody titres for IBDV. The incidence of IBD was further confirmed by pathological studies. The emergence of very virulent (vv) strains of IBDV causing more than $70 \%$ mortality in 1992-93 resulted in heavy economic losses to the poultry industry in the country (Sah et al., 1995). In 1995 OIE conducted a survey in which $95 \%$ of the 65 countries responded announced the presence of infectious bursal disease infection (Eterradossi, 1995), including New Zealand which had been free of disease until 1993 (Jones, 1986). However, percent morbidity and mortality varied from place to place. Factors like the strains of the virus involved, age of birds, vaccination status, type of vaccine, season, concurrent infections, and immunosuppression affected the morbidity and mortality due to IBD. Epidemiological study of poultry diseases on the basis of data from disease investigation laboratory Hisar, Haryana for the period July 1994 to June 2003 revealed that $8.89 \%$ flocks out of 795 poultry flocks were affected with vvIBDV (Jindal et al., 2004). Similar study for the period July 2005 to June 2008 revealed $4.54 \%$ morbidity with IBD in 483 poultry flocks of Haryana (Mor et al., 2010). Out of these 483 flocks, 334 flocks were vaccinated and 149 flocks were unvaccinated.

Vaccination is one of the important step for successful control of IBD. Live attenuated vaccines of mild, moderate and hot strains of viruses form the most employed type of vaccine at the field level. A number of IBD 
vaccination strategies have been applied in the field and new generation IBD vaccines (vector and complex vaccines) are available in the market (Muller et al., 2012). Chickens from more than one parent flock may be mixed in the same broiler house, adding to the variation in the level of MDA. In order to have chickens protected from IBDV field challenge, it is crucial to determine the optimal timing for IBD vaccine delivery (Tsukamoto et al., 1995). The optimal timing is often predicted based on serological data following detection of IBDV-MDA by an ELISA system during the first week post hatch (Kouwenhoven and Van den Bos, 1994). The "Deventer formula" was developed to estimate the optimal vaccination time based on the half-life time of the MDA, the age of the chicken at sampling, genetic background, and breakthrough titre of the vaccine (De Wit, 2001).

The causes of live-virus vaccination failure are numerous. The emergence of variant or newer strains of the virus in the recent times has also been reported to cause vaccination failures (Moemen et al., 2014). Moreover, various attenuation levels of commercially available live vaccines for IBD lead to varying levels of immunosuppression increasing the birds' vulnerability to various infections. In general, vaccine efficacy highly depends on the dose and strains of the vaccine and challenge viruses, as well as, the route of administration, the appropriate vaccination time, and the levels of maternal antibodies (OIE, 2012). Inspite of extensive control measures the farmers are still facing the problems of Gumboro even in the vaccinated flocks (Hasan et al., 1998; Dias et al., 2009). Control of IBD poses one of the most challenging tasks in the poultry health management. Despite the regular use of IBD vaccines, the disease prevails in Haryana state and affects the flocks of different age groups. The present experimental study was conducted to study humoral immune response by calculating antibody titres against IBDV and immunophenotyping to evaluate the cellular immune response of two live commercially available intermediate plus vaccines in single and twice vaccination strategy.

\section{Materials and Methods}

One hundred and fifty, day old broiler chicks were procured from a local hatchery. The chicks were reared under strict hygienic conditions in the departmental animal house. All the birds were given standard chick feed ad-libidum and provided clean drinking water throughout the experiment. Commercially available live vaccines named $\mathrm{P}$ and $\mathrm{Q}$ belonging to intermediate plus strain of IBDV were used in this study. Optimum day of vaccination was $17^{\text {th }}$ day of age on the basis of maternal antibody titre of the chicks procured (Table 2). Booster vaccination was done on $24^{\text {th }}$ day of age. The birds were grouped into five treatment sub-groups as shown in the Table 1. Birds in group A were sham-immunized with sterile vaccine diluent. Birds in group B1 and B2 were immunized with recommended doses of intermediate plus vaccine $\mathrm{P}$ at $17^{\text {th }}$ day of age. The birds of group B2 were given booster dose of vaccine $\mathrm{P}$ at $24^{\text {th }}$ day of age. Similarly birds of group $\mathrm{C} 1$ and $\mathrm{C} 2$ were immunized with recommended doses of intermediate plus vaccine $\mathrm{Q}$ at $17^{\text {th }}$ day of age. The birds in group $\mathrm{C} 2$ were given booster dose of vaccine $\mathrm{Q}$ at $24^{\text {th }}$ day of age. Vaccines were administered via the recommended intraocular route.

Blood was collected and then birds were sacrificed at different intervals in all the groups as detailed in the Table 1 . Serum was separated from all the samples and stored at $20^{\circ} \mathrm{C}$ till further use. Birds were weighed before sacrificing and weight of bursa was 
recorded after sacrifice for calculation of bursal index. Maternal antibody titre was evaluated in chicks on 1, 7, 14 days of age (doa) before vaccination using standard IBD ELISA kit. Ten birds from group A were used at each interval for estimation of maternal antibodies. Humoral immune responseantibody titres to IBDV was estimated in serum samples on 7, 14, 21, and 28 days post vaccination (DPV). Six birds from each group were used at weekly interval.

An indirect enzyme linked immunosorbent assay was performed to detect the IBD antibody levels using IDEXX-IBD-ELISA kit (IDEXX, Westbrook, USA). The test was performed as per the manufacturer's instructions. Serum samples were diluted five hundred fold (1:500) with serum diluent and $100 \mu \mathrm{l}$ of the diluted samples were added to the antigen coated wells. Positive and negative controls were included every time in the test. The plates were incubated at $18-26^{\circ} \mathrm{C}$ for $30 \mathrm{~min}$. The contents of the wells were removed and the wells were washed three times with distilled water. Care was taken to avoid the drying of plate in between plate washings and prior to the addition of the next reagent. Plates were tapped onto absorbent material after the final wash to remove any residual wash fluid and after that $100 \mu \mathrm{l}$ of Goat Anti chicken Horse radish peroxidase conjugate was added to each well.

The plates were incubated at $18-26^{\circ} \mathrm{C}$ for 30 minutes. The plates were emptied and washed thrice with distilled water. The residual droplets were removed by lightly tapping the plate over a filter paper pad. One hundred microliters of TMB substrate was added to each well and incubated in dark at $18-26^{\circ} \mathrm{C}$ for 15 minutes. Later, $100 \mu$ of stop solution was added to each well to stop the colour reaction. The absorbance values were measured at $650 \mathrm{~nm}$ wavelength in an ELISA reader.
Assay was considered to be valid only when the difference between positive control mean and negative control mean (PCX - NCX) was greater than 0.075 . The negative control mean absorbance should be less than or equal to 0.150. Serum samples with $\mathrm{S} / \mathrm{P}$ ratios of greater than or equal to 0.2 (titers greater than 396) were considered as positive. The presence or absence of antibody to IBD was determined by relating the A (650) value of the unknown to the positive control mean. Antibody titre was calculated using the equations provided in the ELISA kit.

\section{Calculation}

\section{Controls}

Negative control mean, $\mathrm{NC} \overline{\mathrm{x}}=\frac{\mathrm{NC1} \mathrm{A}(650)+\mathrm{NC} 2 \mathrm{~A}(650)}{2}$

NC1- Negative Control 1 value, NC2Negative Control 2 value

Positive control mean,

$$
\mathrm{PC} \overline{\mathrm{x}}=\frac{\mathrm{PC} 1 \mathrm{~A}(650)+\mathrm{PC} 2 \mathrm{~A}(650)}{2}
$$

PC1- Positive Control 1value, PC2- Positive Control 2 value

\section{Validity criteria}

$\mathrm{PC}^{\overline{\mathbf{x}}}-\mathrm{NC}^{\overline{\mathbf{x}}}>0.075$

$\mathrm{NC} \overline{\mathbf{x}} \leq 0.150$

\section{Samples}

The relative level of antibody in the sample was determined by calculating sample to positive $(\mathrm{S} / \mathrm{P})$ ratio.

Sample to positive ratio, $\mathrm{S} / \mathrm{P}=\frac{\frac{\text { Sample Mean }-\mathrm{NCF}}{\mathrm{PC} \overline{\mathrm{x}}-\mathrm{NC} \overline{\mathrm{x}}}}{}$

Endpoint titres were calculated using equation

$\log _{10}$ Titer $=1.09\left(\log _{10} \mathrm{~S} / \mathrm{P}\right)+3.36^{*}$ 
* relates $\mathrm{S} / \mathrm{P}$ at a 1: 500 dilution to an end point titre

\section{IDEXX ELISA standard for IBD antibody titre}

S/P value Titre range Antibody status $<0.20<396 \quad$ negative

$\geq 0.20 \quad \geq 396 \quad$ positive

The optimal age of vaccination was determined by the Deventer formula (De Wit, 1998)

Vaccination age $=\{(\log 2$ titre bird $\%-\log 2$ breakthrough) $\left.\mathrm{x} \mathrm{t}_{-}\right\}+$age at sampling + correction0-4

In which

Bird $\%=$ ELISA titre of the bird representing a certain percentage of the flock.

Breakthrough $=$ breakthrough (ELISA) titre of the vaccine to be used (500 for intermediate plus vaccine)

$\mathrm{t}_{-}=$half-life time (ELISA) of the antibodies in the type of chickens being sampled (3.0 days)

Age at sampling $=$ age of the birds at sampling (1 day of age)

Correction 0-4 = extra days when the sampling was done at 0 to 4 days of age ( 3 for day old chicks)

\section{Immunophenotyping}

For cell mediated immune response CD4+ and CD8+ subset distribution was assessed after vaccination by flow cytometry (Chhabra et al., 2015). Peripheral blood mononuclear cells (PBMCs) were separated from the blood of birds on 14, 21 and 28 days post vaccination for this purpose. To determine the percentage of T- lymphocytes subpopulations, $1 \mathrm{ml}$. blood was collected from wing vein in heparin tubes and further diluted (1:1) with RPMI-1640 medium (Sigma-Aldrich, UK). The prepared blood samples ( $1 \mathrm{ml}$ each) were then over layered onto $1 \mathrm{ml}$ of Histopaque1.077 gradient (Sigma-Aldrich, UK) and centrifuged in $2 \mathrm{ml}$ Eppendorf vials at 10000 rpm for 90 seconds.

After centrifugation, the buffy coat formed of mononuclear cells was gently collected, washed twice with RPMI-1640 medium and adjusted to $1 \times 10^{7}$ cells $/ \mathrm{ml}$. The cells were resuspended in $0.5 \%$ bovine serum albumin (BSA, Sigma-Aldrich, UK) in PBS (blocking solution) and incubated at room temperature for 15 minutes.

The sample $(100 \mu \mathrm{l})$ was incubated with antibodies against surface domains of $\mathrm{CD} 4$ (mouse anti-chicken CD4-FITC clone, $0.1 \mathrm{mg} / \mathrm{ml}$ ) and CD8 (mouse anti-chicken CD8-FITC clone, $0.1 \mathrm{mg} / \mathrm{ml}$ ) receptors of $\mathrm{T}$ lymphocytes separately for 30 minutes in dark. Spin down and wash with PBS. Resuspend in $2 \%$ paraformaldehyde.

The stained cells were detected by flow cytometry (BD Accuri C6, BD Bioscience San Jose, CA, USA) to count the T lymphocytes. The unstained cell sample was used as a negative control to adjust the threshold.

\section{Statistical analysis}

One-way analysis of variance (ANOVA) test, followed by Duncan post hoc test was used to determine the statistically significant differences in mean values of humoral, cellular immune response between the experimental groups. Alpha was set at $95 \%$. Statistical software SPSS ${ }^{\mathrm{TM}} 20.0$ (IBM, Corp. USA) was used. 


\section{Results and Discussion}

\section{Humoral immune response}

\section{Calculation of age of first IBD vaccination in experimental chicks}

The ELISA MAb titre of chicks procured for the experiment is presented in Table 2 . The level of MAbs in these chicks ranged from 6834.6 to 9925.60 . The day of vaccination was calculated for all the individual samples. As per Deventer formula the chicken with lowest titre of 6834.6 can be vaccinated at 16 day of age while chicken with highest titre of 9925.60 can be vaccinated on 17 day of age which is a good sign of uniformity as difference in day of vaccination between them is less than 4 days. To determine when $75 \%$ (default percentage as per Deventer formula) of the flock can be vaccinated, the highest titres (representing 25\% of the flock) are skipped. So we vaccinated our experimental flock on 17 day of age.

\section{Maternal antibody titres in experimental chicks before vaccination}

The level of ELISA MAb titres at day old, $7^{\text {th }}$ day and $14^{\text {th }}$ day of age before vaccination are presented in Table 3. The mean titre of ten chicks at respective intervals was 7874.21, 2449.4 and 1089.9. The mean MAb titre shows a steady decline in the titre from day old age to $14^{\text {th }}$ day of age. Similar study was done by Fantay et al., (2015) who determined the rate of maternal antibodies transfer from parent birds to chicks by using ELISA and determined proper age of vaccination of chickens against IBD and concluded that transfer rate was $56.5 \%$ and proper time for administration of live intermediate IBD vaccine was 18 days. They suggested that chicks should not be vaccinated without determining the maternal antibody levels. Besseboua et al., (2015) determined optimal time of vaccination against IBDV (Gumboro) in Algeria. It was noticed that on day 1 the chicks contained a high level (6400.54 \pm 2993.67) of maternally derived antibody that gradually decreased below a positive level within 21 days (365.86 \pm 634.46$)$.

\section{ELISA antibody titres against IBD vaccines in experimental birds}

The comparison of mean antibody titres against IBD vaccination in broiler chicken at different interval is presented in Table 4 and Figure 1. The birds administered with single intermediate plus vaccine $\mathrm{P}$ (group B), induced a mean antibody titre of 651.5 on 7DPV (24 doa), 4278.8 on 14 DPV (31 doa), 4290.8 on 21 DPV (38 doa) and 4521.3 on 28 DPV (45 doa). Birds vaccinated with single dose of intermediate plus vaccine Q (group C), exhibited mean antibody titre of 2128.98 on 7 DPV (24doa), 3184.6 on 14 DPV (31 doa), 3683.6 on 21 DPV (38 doa) and 5011.8 on 28 DPV (45 doa). Birds with vaccine P developed lower antibody titre at 7 DPV but higher titres at 14 and 21 DPV and comparable titres at $28 \mathrm{DPV}$ when compared to group $\mathrm{C} 1$ with vaccine $\mathrm{Q}$.

Birds administered with double vaccination of intermediate plus vaccine $\mathrm{P}$ (group B2), induced a mean antibody titre of 3899.4 on 14 DPV (31 doa), 3549.1 on 21 DPV (38 doa) and 4878.9 on 28 DPV (45 doa). Birds vaccinated with double intermediate plus vaccine $\mathrm{Q}$ (group $\mathrm{C} 2$ ), exhibited mean antibody titre of 4353.7 on 14 DPV (31 doa), 3850.9 on 21 DPV (38 doa) and 4315.2 on 28 DPV (45 doa). Antibody titres of birds with vaccine $P$ double vaccination were lower than birds with vaccine $\mathrm{Q}$ double vaccination at 14 DPV only and thereafter they are comparable with each other. The comparison of ELISA $\mathrm{Ab}$ titres against IBD with respect to single and double vaccination with vaccine $P$ revealed significantly higher titres in single 
vaccination as compared to double vaccination at 14 and $21 \mathrm{DPV}$ which became comparable at 28 DPV (45 doa). However the comparison of ELISA Ab titres against IBD with respect to single and double vaccination with vaccine $Q$ revealed significantly higher titre in double vaccination at 14 DPV (31 doa) only and comparable at 21 (38 doa) and 28 DPV (45 doa).

The results of ELISA $\mathrm{Ab}$ titre in our study revealed that protective antibody titres developed in the vaccinated birds at 7 DPV with both the vaccines $\mathrm{P}$ and $\mathrm{Q}$. however, the antibody titres were significantly higher in birds of group $\mathrm{C}$ (vaccine Q) as compared to birds of group B (vaccine P) at 7 DPV itself. Padmaja et al., (2015) suggested the use of either a single dose of intermediate plus vaccine strain or two doses of intermediate vaccine strain for enhanced protection in disease endemic regions with circulating maternal derived antibodies.

\section{Cell mediated immune response by immunophenotyping}

The CD4+ and CD8+ subset distribution was assessed after vaccination by flow cytometry (Chhabra et al., 2015). Peripheral blood mononuclear cells (PBMCs) were separated from the blood of birds on 7, 14, 21 and 28 days post vaccination for this purpose. Histogram of FITC (fluorescein isothiocynate) labeled CD4+ and CD8+ cells are presented in Figure 2.

Table.1 Experimental design

\begin{tabular}{|l|l|l|l|l|l|}
\hline Group & Immunogen & $\begin{array}{l}\text { Sub } \\
\text { group }\end{array}$ & $\begin{array}{l}\text { Immunization } \\
\text { (days of age) }\end{array}$ & $\begin{array}{l}\text { Bleeding (days of } \\
\text { age/DPV) }\end{array}$ \\
\hline & & & $\begin{array}{l}\text { First } \\
\text { vaccination }\end{array}$ & Booster vaccination & \\
\hline $\begin{array}{l}\text { A } \\
(\mathrm{n}=60)\end{array}$ & $\begin{array}{l}\text { Vaccine } \\
\text { diluent }\end{array}$ & A & Day-17 & -- & $\begin{array}{l}1,7,14 \text { day of age } \\
7,14,21,28 \text { DPV }\end{array}$ \\
\hline $\begin{array}{l}\text { B } \\
(\mathrm{n}=45)\end{array}$ & Vaccine P & $\begin{array}{l}\text { B-1 } \\
(25)\end{array}$ & Day-17 & -- & $7,14,21,28$ DPV \\
\cline { 3 - 6 } & & $\begin{array}{l}\text { B-2 } \\
(20)\end{array}$ & Day-17 & $\begin{array}{l}\text { Booster -7 days after first } \\
\text { vaccination at day - 24 }\end{array}$ & $\begin{array}{l}14,21,28 \text { DPV (first } \\
\text { vaccine) })\end{array}$ \\
\hline $\begin{array}{l}\mathrm{C} \\
(\mathrm{n}=45)\end{array}$ & Vaccine Q & $\begin{array}{l}\mathrm{C}-1 \\
(25)\end{array}$ & Day-17 & -- & $7,14,21,28$ DPV \\
\cline { 2 - 6 } & & $\begin{array}{l}\text { C-2 } \\
(20)\end{array}$ & Day-17 & $\begin{array}{l}\text { Booster -7 days after first } \\
\text { vaccination at day- 24 }\end{array}$ & $\begin{array}{l}14,21,28 \text { DPV (first } \\
\text { vaccine) }\end{array}$ \\
\hline
\end{tabular}

Table.2 Maternal antibody titre and day of vaccination in day old chicks

\begin{tabular}{|c|c|c|}
\hline Sr. No. & Titre & Day of vaccination \\
\hline 1 & 6834.6 & 16 \\
\hline 2 & 6890.4 & 16 \\
\hline 3 & 6894.9 & 16 \\
\hline 4 & 6941.7 & 16 \\
\hline 5 & 6991.5 & 16 \\
\hline 6 & 8083.7 & 16 \\
\hline 7 & 8445.9 & 17 \\
\hline 8 & 8750.12 & 17 \\
\hline 9 & 8983.65 & 17 \\
\hline 10 & 9925.60 & 17 \\
\hline
\end{tabular}


Table.3 Maternal antibody titres of broiler chicks at different age before vaccination

\begin{tabular}{|c|c|c|c|}
\hline Sr. No. & day old & 7 day age & 14 day age \\
\hline 1 & 6834.6 & 1569.4 & 379.3 \\
\hline 2 & 6890.4 & 1659.7 & 435.0 \\
\hline 3 & 6894.9 & 1750.8 & 494.9 \\
\hline 4 & 6941.7 & 1688.0 & 815.5 \\
\hline 5 & 6991.5 & 2446.1 & 864.8 \\
\hline 6 & 8083.7 & 2798.7 & 912.0 \\
\hline 7 & 8445.9 & 3041.7 & 1206.1 \\
\hline 8 & 8750.12 & 3123.0 & 1317.8 \\
\hline 9 & 8983.65 & 3163.5 & 1533.0 \\
\hline 10 & 9925.60 & 3253.0 & 2940.5 \\
\hline MEAN \pm SE & $7874.21 \pm 353.29^{\mathrm{a}}$ & $2449.4 \pm 224.80$ & $1089.9 \pm 238.79^{\mathrm{c}}$ \\
\hline
\end{tabular}

Mean with different superscripts are significantly different $(\mathrm{p}<0.05)$.

Table.4 Comparison of mean antibody titres of IBD intermediate plus vaccine $\mathrm{P}$ and $\mathrm{Q}$ in single and double vaccinated broiler chickens

\begin{tabular}{|c|c|c|c|c|c|c|c|}
\hline \multicolumn{8}{|c|}{ Mean antibody titre with standard error } \\
\hline & & & control & & ine $\mathrm{P}$ & & e $\mathrm{Q}$ \\
\hline $\begin{array}{l}\text { Sr. } \\
\text { No }\end{array}$ & $\begin{array}{c}\text { Day } \\
\text { of } \\
\text { age }\end{array}$ & $\begin{array}{c}\text { Day Post } \\
\text { Vaccinat } \\
\text { ion } \\
\text { (DPV) }\end{array}$ & $\begin{array}{l}\text { Group A } \\
\text { (control) }\end{array}$ & $\begin{array}{c}\text { Group B1 } \\
\text { (V-17 } \\
\text { DOA) }\end{array}$ & $\begin{array}{l}\text { Group B2 } \\
\left(\mathrm{V}-17^{\text {th }} \text { and }\right. \\
24^{\text {th }} \text { DOA) }\end{array}$ & $\begin{array}{c}\text { Group C1 } \\
{\text { (V- } 17^{\text {th }}}^{\text {DOA) }}\end{array}$ & $\begin{array}{l}\text { Group C2 } \\
\text { (V-1 } 7^{\text {th }} \text { and } \\
24 \text { thDOA) }\end{array}$ \\
\hline 1 & 1 & & $\begin{array}{l}7874.2 \pm \\
353.29^{\mathrm{a}}\end{array}$ & & & & \\
\hline 2 & 7 & & $\begin{array}{l}2449.4 \pm \\
224.80^{\mathrm{b}}\end{array}$ & & & & \\
\hline 3 & 14 & & $\begin{array}{l}1089.9 \pm \\
238.79^{\mathrm{c}}\end{array}$ & & & & \\
\hline 4 & 24 & 7 & $\begin{array}{l}138.2 \pm \\
21.32^{\mathrm{a}}\end{array}$ & $\begin{array}{l}651 . \pm \\
73.33^{\mathrm{b}}\end{array}$ & $\begin{array}{l}651.5 \pm \\
73.33^{\mathrm{b}}\end{array}$ & $\begin{array}{l}2128.9 \pm \\
238.3^{\mathrm{c}}\end{array}$ & $\begin{array}{c}2128.98 \pm \\
238.3^{\mathrm{c}}\end{array}$ \\
\hline 5 & 31 & 14 & $\begin{array}{r}105.83 \pm \\
13.74^{\mathrm{a}} \\
\end{array}$ & $\begin{array}{l}4278 . \pm \\
115.98^{\mathrm{b}}\end{array}$ & $\begin{array}{l}3899.4 \pm \\
141.36^{\mathrm{c}}\end{array}$ & $\begin{array}{l}3184.6 \pm \\
236.15^{\mathrm{d}}\end{array}$ & $\begin{array}{l}4353.7 \pm \\
154.84^{\mathrm{b}} \\
\end{array}$ \\
\hline 6 & 38 & 21 & $\begin{array}{c}76.59 \pm \\
5.68^{\mathrm{a}}\end{array}$ & $\begin{array}{l}4290 . \pm \\
219.28^{\mathrm{b}}\end{array}$ & $\begin{array}{l}3549.1 \pm \\
124.90^{\mathrm{c}}\end{array}$ & $\begin{array}{l}3683.6 \pm \\
185.03^{c}\end{array}$ & $\begin{array}{l}3850.9^{ \pm} \\
91.35^{\mathrm{c}}\end{array}$ \\
\hline 7 & 45 & 28 & $\begin{array}{l}6.05 \pm \\
2.04^{\mathrm{a}} \\
\end{array}$ & $\begin{array}{l}4521 . \pm \\
187.76^{\mathrm{b}}\end{array}$ & $\begin{array}{l}4878.9 \pm \\
218.29^{\mathrm{b}}\end{array}$ & $\begin{array}{l}5011.8 \pm \\
173.75^{\mathrm{b}}\end{array}$ & $\begin{array}{l}4315.2 \pm \\
154.76^{\mathrm{b}}\end{array}$ \\
\hline
\end{tabular}

Means with different superscripts are significantly different $(\mathrm{p}<0.05)$ within same row Means of control group A at 1, 7 and 14 day age are significantly different $(\mathrm{p}<0.05)$ 
Table.5 Percent CD4+ cells population in PBMCs from single and double IBD vaccinated broiler chickens vaccinated with Intermediate Plus Vaccines P and Q

\begin{tabular}{|c|c|c|c|c|c|c|}
\hline \multirow{2}{*}{$\begin{array}{l}\text { Age of } \\
\text { chicks } \\
\text { (in days) }\end{array}$} & \multirow{2}{*}{$\begin{array}{l}\text { Day post } \\
\text { vaccination } \\
\text { (DPV) }\end{array}$} & \multirow{2}{*}{$\begin{array}{l}\text { Vaccine } \\
\text { diluent on } \\
17^{\text {th }} \text { DOA }\end{array}$} & \multicolumn{2}{|c|}{ Vaccine $\mathrm{P}$ on } & \multicolumn{2}{|c|}{ Vaccine $\mathrm{Q}$ on } \\
\hline & & & $17^{\text {th }}$ DOA & $\begin{array}{l}17^{\text {th }} \text { and } 24^{\text {th }} \\
\text { DOA }\end{array}$ & $17^{\text {th }}$ DOA & $\begin{array}{l}17^{\text {th }} \text { and } 24^{\text {th }} \\
\text { DOA }\end{array}$ \\
\hline & & $\begin{array}{l}\text { Group A } \\
\text { (control) }\end{array}$ & Group B1 & Group B2 & Group C1 & Group C2 \\
\hline 24 & 7DPV & $\begin{array}{l}10.6 \pm \\
0.93^{\mathrm{a}}\end{array}$ & $\begin{array}{l}18.8 \pm \\
1.73^{\mathrm{b}}\end{array}$ & $\begin{array}{l}18.8 \pm \\
1.73^{b}\end{array}$ & $\begin{array}{l}20.4 \pm \\
1.63^{\mathrm{b}}\end{array}$ & $\begin{array}{l}20.4 \pm \\
1.63^{\mathrm{b}}\end{array}$ \\
\hline 31 & 14 DPV & $\begin{array}{l}12.1 \pm \\
0.25^{\mathrm{a}}\end{array}$ & $\begin{array}{l}5.0 \pm \\
0.24^{b}\end{array}$ & $\begin{array}{l}9.5 \pm \\
1.89^{\mathrm{c}}\end{array}$ & $\begin{array}{l}8.5 \pm \\
0.84^{\mathrm{c}}\end{array}$ & $\begin{array}{l}11.4 \pm \\
1.49^{\mathrm{ac}}\end{array}$ \\
\hline 38 & $21 \mathrm{DPV}$ & $\begin{array}{l}10.4 \pm \\
0.32^{\mathrm{a}}\end{array}$ & $\begin{array}{l}4.2 \pm \\
0.74^{\mathrm{c}}\end{array}$ & $\begin{array}{l}8.9 \pm \\
0.03^{\mathrm{ab}}\end{array}$ & $\begin{array}{l}6.5 \pm \\
0.18^{\mathrm{bc}}\end{array}$ & $\begin{array}{l}8.1 \pm \\
0.33^{\text {ab }}\end{array}$ \\
\hline 45 & $28 \mathrm{DPV}$ & $\begin{array}{l}9.4 \pm \\
0.06^{a}\end{array}$ & $\begin{array}{l}13.6 \pm \\
1.4^{\mathrm{b}}\end{array}$ & $\begin{array}{l}12.9 \pm \\
0.07^{\mathrm{b}}\end{array}$ & $\begin{array}{l}10.6 \pm \\
1.22^{\mathrm{ab}}\end{array}$ & $\begin{array}{l}9.1 \pm \\
1.08^{a}\end{array}$ \\
\hline
\end{tabular}

Means with different superscripts are significantly different $(\mathrm{p}<0.05)$ within same row

Table.6 Percent CD8+ cells population in PBMCs from single and double IBD vaccinated broiler chickens vaccinated with Intermediate Plus Vaccine P and Q

\begin{tabular}{|c|c|c|c|c|c|c|}
\hline \multirow{2}{*}{$\begin{array}{l}\text { Age of } \\
\text { chicks } \\
\text { (in days) }\end{array}$} & \multirow{2}{*}{$\begin{array}{c}\text { Day post } \\
\text { vaccination } \\
\text { (DPV) }\end{array}$} & \multirow{2}{*}{$\begin{array}{c}\text { Vaccine } \\
\text { diluent on } 17^{\text {th }} \\
\text { DOA }\end{array}$} & \multicolumn{2}{|c|}{ Vaccine $\mathrm{P}$ on } & \multicolumn{2}{|c|}{ Vaccine $Q$ on } \\
\hline & & & $17^{\text {th }}$ DOA & $\begin{array}{c}17^{\text {th }} \text { and } 24^{\text {th }} \\
\text { DOA }\end{array}$ & $17^{\text {th }}$ DOA & $\begin{array}{c}17^{\text {th }} \text { and } 24^{\text {th }} \\
\text { DOA }\end{array}$ \\
\hline & & $\begin{array}{l}\text { Group A } \\
\text { (control) }\end{array}$ & Group B1 & Group B2 & Group C1 & Group C2 \\
\hline 24 & 7DPV & $8.0 \pm 0.40^{\mathrm{a}}$ & $8.5 \pm 1.06$ & $8.5 \pm 1.06^{a}$ & $13.2 \pm 1.89$ & $13.2 \pm 1.89$ \\
\hline 31 & $14 \mathrm{DPV}$ & $7.5 \pm 0.21^{\mathrm{a}}$ & $3.5 \pm 0.3^{\mathrm{a}}$ & $4.4 \pm 0.58^{\mathrm{a}}$ & $3.7 \pm 0.85^{\mathrm{a}}$ & $3.8 \pm 0.67^{\mathrm{a}}$ \\
\hline 38 & $21 \mathrm{DPV}$ & $6.7 \pm 0.32^{\text {ab }}$ & $5.5 \pm 0.77^{\mathrm{bc}}$ & $6.1 \pm 0.61^{\mathrm{c}}$ & $4.2 \pm 0.91^{\mathrm{ab}}$ & $2.8 \pm 0.13^{\mathrm{a}}$ \\
\hline 45 & $28 \mathrm{DPV}$ & $6.9 \pm 0.29^{\mathrm{a}}$ & $6.8 \pm 0.58^{\mathrm{c}}$ & $5.4 \pm 0.65^{b c}$ & $4.4 \pm 0.31^{\mathrm{ab}}$ & $4.7 \pm 0.33^{b}$ \\
\hline
\end{tabular}

Means with different superscripts are significantly different $(\mathrm{p}<0.05)$ within same row.

Fig.1 Comparison of mean antibody titre in single and double IBD vaccinated broiler chickens vaccinated with Intermediate Plus Vaccines P and Q

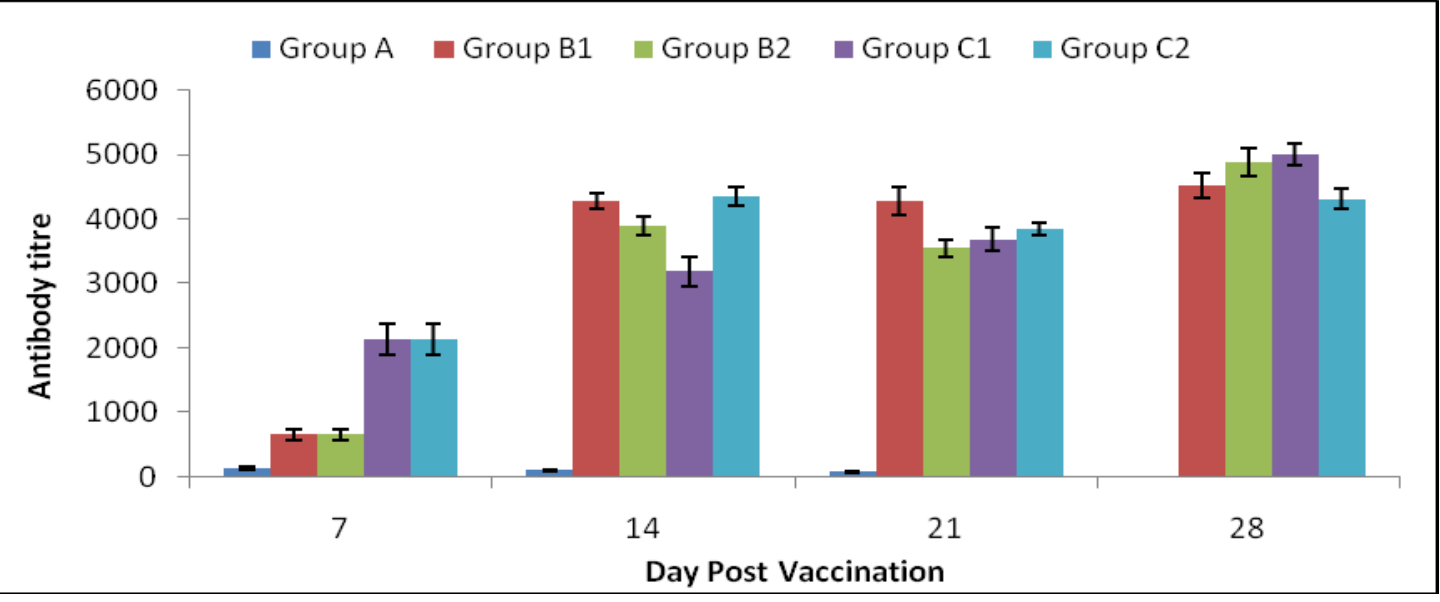


Fig.2 Flow cytometry histogram of chicken lymphocytes showing FITC labeled CD4+ cells (a) to (d) and CD8+ cells (e \& f) along with control groups

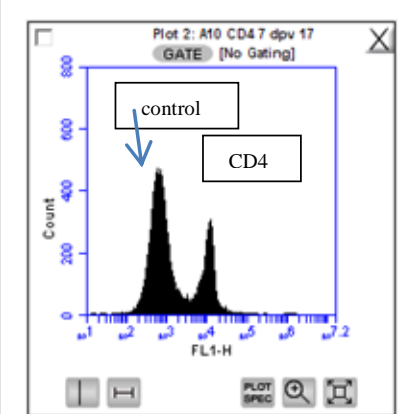

(a)

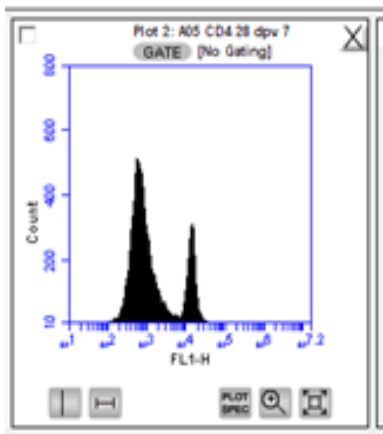

(d)

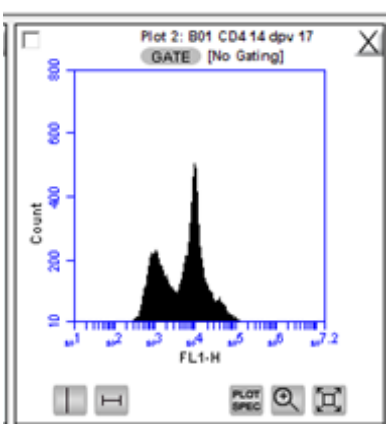

(b)

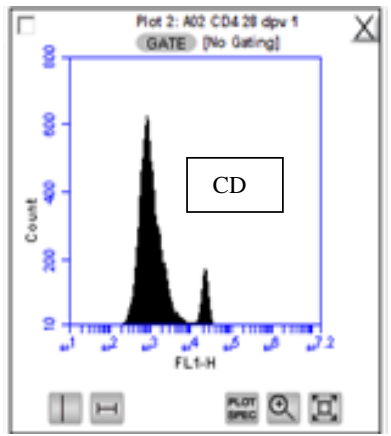

(e)

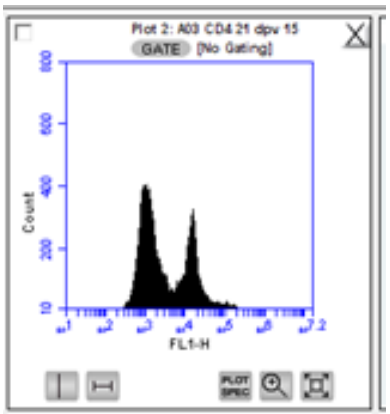

(c)

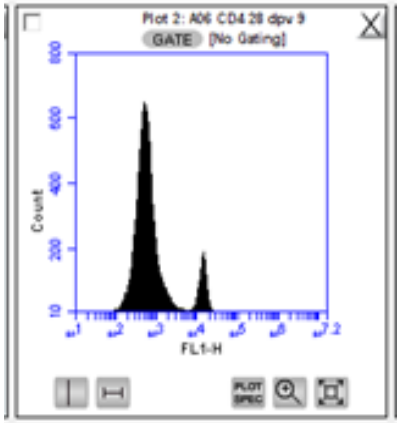

(f)

Fig.3 Comparison of CD4+ cells in PBMCs from single and double IBD vaccinated broiler chickens vaccinated with Intermediate Plus Vaccines P and Q

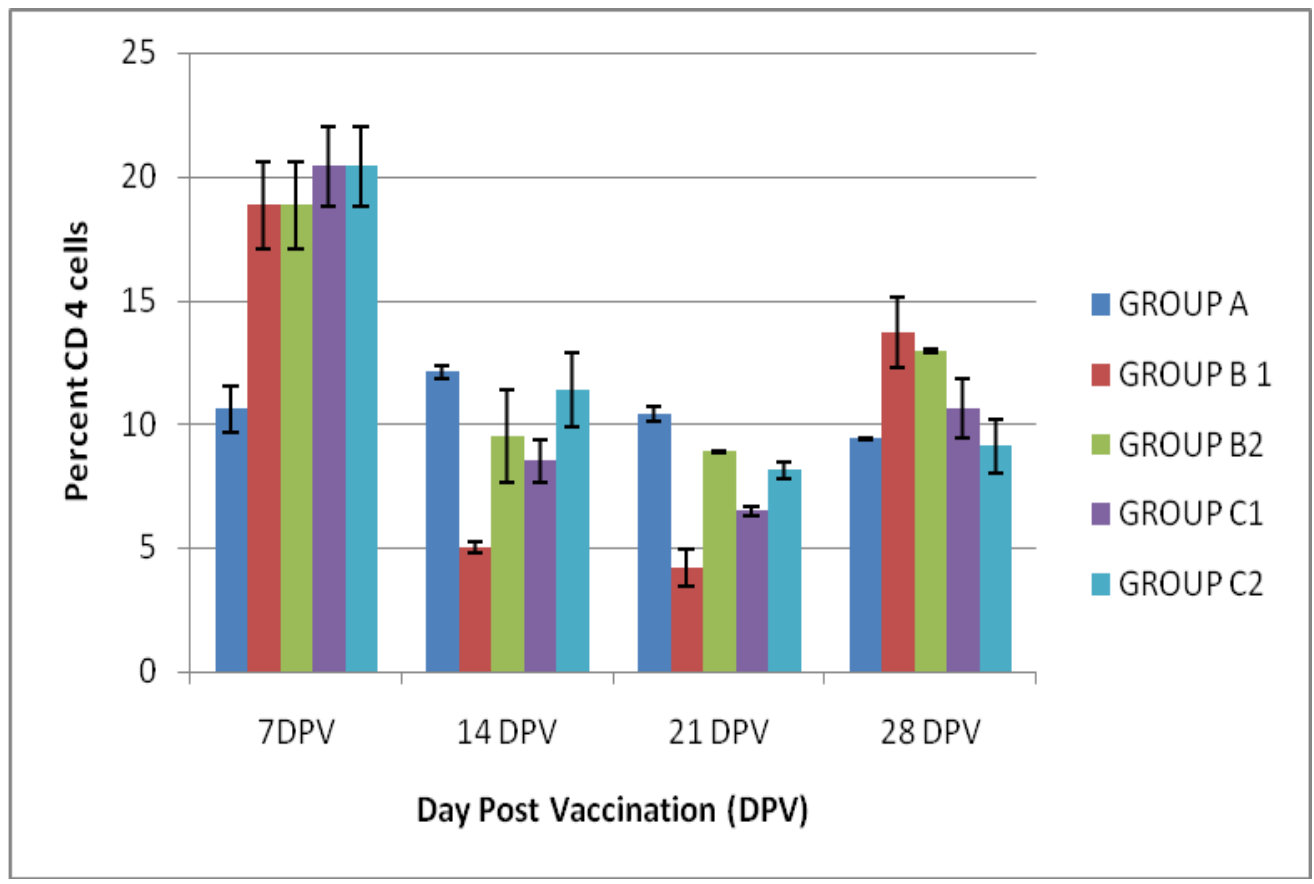


Fig.4 Comparison of CD8+ cells in single and double IBD vaccinated broiler chickens vaccinated with Intermediate Plus Vaccines P and Q

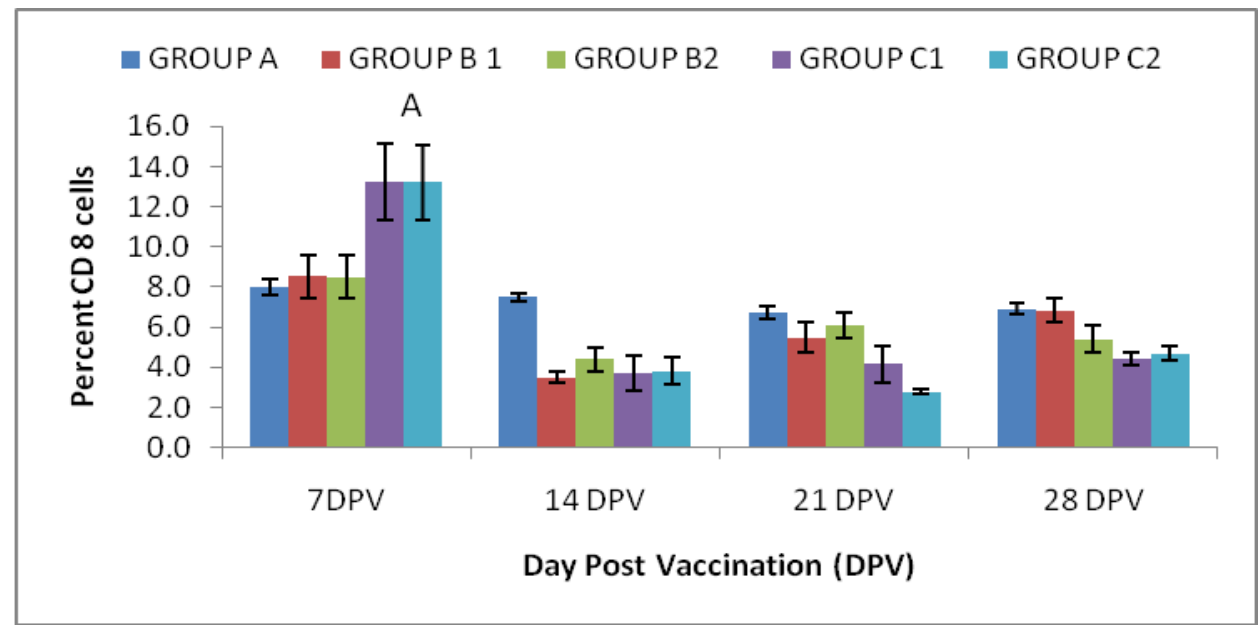

\section{CD4+ cells population in IBD vaccinated birds}

The CD4+ cells were $10.6 \%$ at 7 DPV (24 doa) in sham immunized group (control) as shown in Table 5 and Figure 3. The vaccinated groups revealed a significant increase in percent CD4+ cells (18.8 and 20.4), 7 days after first vaccination. Later at 14 and 21 DPV the CD4+ cells decreased in all the vaccinated groups as compared to control. However, the CD4+ cells again revealed an increased level in all the vaccinated groups at $28 \mathrm{DPV}$.

Birds with vaccine $\mathrm{P}$ (group B) at 17 doa, showed significantly higher CD4+ cell population (18.8\%) at $7 \mathrm{DPV}$, which later decreased at 14 and $21 \mathrm{DPV}$ with a level of $5.0 \%$ and $4.2 \%$ respectively. However, again there was increase in the CD4+ population $(13.6 \%)$ at 28 DPV. Similar trend of CD4+ cell population were observed in birds with vaccine Q (group C) at 17 doa. Birds with vaccine $\mathrm{Q}$ also showed significantly higher CD4+ cell population (20.4\%) at 7 DPV and a decreasing trend at 14 and 21 DPV with a level of $8.5 \%$ and $6.5 \%$ respectively. In this group also, again there was increase in the CD4+ population (10.6\%) at $28 \mathrm{DPV}$.

\section{CD8+ cells population in IBD vaccinated birds}

The CD8+ cells were $8.0 \%$ at 7 DPV (24 doa) in control (Table 6 and Figure 4). The CD 8 cells increased in vaccinated groups as compared to control group at 7 DPV but this increase was not significant in vaccine $P$ groups, however, in vaccine $\mathrm{Q}$ groups this increase was significant. Birds with vaccine $P$ showed little higher CD8+ cell population $(8.5 \%)$ at 7 DPV, without statistical difference as compared to control. Thereafter the CD8+ cells decreased at 14 DPV with a level of $3.5 \%$ and again it increased to 5.5 and 6.8 percent at 21 and 28 DPV respectively but remain lower than the birds of control. The CD8+ cell population was significantly higher (13.2\%) in birds with vaccine Q at 7 DPV as compared to birds of control. In this group also the CD8+ cells decreased at 14 DPV with a level of $3.7 \%$ and again it increased to 4.2 and 4.4 percent at 21 and 28 DPV respectively but remain lower than the birds of control group.

As detailed above there was increase in both CD4+ and CD8+ cells in the vaccinated groups at 7 DPV. Thereafter there was decrease in CD4+ and CD8+ cells at 14 and 
21 DPV but again increase at 28 DPV. This decrease in CD4+ and CD8+ cells at 14 and $21 \mathrm{DPV}$ is probably due immunosuppressive effect of IBD vaccines which also correlates with the bursal index and bursal changes in different groups. Further studies are required to strengthen the observation with respect to flow cytometry analysis.

A similar study was done by Padmaja and Krishnamohan Reddy. (2015) on immunophenotyping of chicken vaccinated with intermediate and intermediate plus vaccines by flow cytometric analysis. Significant increase in the CD8+ cells from 7 day post vaccination without any major difference in proportions of CD4+ lymphocytes post vaccination suggested the increased role of T-cells in development of protective immunity against the disease. The study warrants the use of intermediate plus vaccines in disease endemic regions and intermediate in non-endemic regions to prevent IBD infection.

Both vaccines $\mathrm{P}$ and $\mathrm{Q}$ provided protective immunity from 7 DPV till the end of experiment (45 days/ 28DPV). In our study age of vaccination came 17 day of age because maternal antibody titre was uniform and high. The mean MAb titre showed a steady decline in the titre from day old age to $14^{\text {th }}$ day of age. The antibody titres after vaccination with vaccine $P$ and $Q$ were protective from 7 DPV in both single and double vaccinated groups indicating protection in all groups. However, the vaccine $\mathrm{Q}$ seemed to be little more invasive as compared to vaccine $\mathrm{P}$ as it induces the immunosuppressive changes in bursa at 7 DPV itself. CD4+ cells increased at 7 DPV, decreased at 14 and $21 \mathrm{DPV}$, again increased at 28 DPV. CD8+ cells also increased at 7 DPV, decreased at 14 DPV, again increased at 21 and 28 DPV probably due to immunosuppressive effect of IBD vaccine.
Further studies are required to strengthen the observation with respect to flow cytometric analysis.

\section{Acknowledgements}

The authors are very thankful to Dr. Renu Gupta, Dr. Yogesh Bangar and Dr. D.S. Dalal for their help. The assistance provided by laboratory staff is also highly appreciated.

\section{References}

Asrani, R.K., Krishnaswamy, D., Narang, G., Kharole, M.U. and Krishnaswamy, S. 1993. Investigation on prevalence and immunological aspects of infectious bursal disease. In: Proceeding of $\mathrm{X}^{\text {th }}$ World Veterinary Poultry Association Congress, Sydney (Australia). Pp. 159.

Benton, W., Cover, M. and Rosenberger, J. 1967. Studies on the transmission of the infectious bursal agent (IBA) of chickens. Avian Dis. 11(1): 430-438.

Besseboua, O., Ayad, A. and Benbarek, H. 2015. Determination of the optimal time of vaccination against infectious bursal disease virus (Gumboro) in Algeria. Onderstepoort J. Vet. Res. 82(1): 01-06.

Chettle, N.J., Stuart, J.C. and Wyeth, P.J. 1989. Outbreaks of virulent infectious bursal disease in East Anglia. Vet. Rec. 125: 271-272.

Cheville, N. 1967. Studies on the pathogenesis of Gumboro disease in the bursa of Fabricius, spleen and thymus of the chicken. Am. J. Pathol. 51: 527551.

Chhabra, R., Forrester, A., Lemiere, S., Awad, F., Chantrey, J. and Ganapathy, K. 2015. Mucosal, cellular, and humoral immune responses induced by different live infectious bronchitis virus vaccination regimes and protection conferred against infectious bronchitis virus Q1 strain. Clin. Vaccine Immunol. 
22: $1050-1059$.

Cosgrove, A.S. 1962. An apparently new disease of chickens-avian nephrosis. Avian Dis. 6: 385-389.

De Wit, J.J. 2001. Gumboro Disease: estimation of optimal time of vaccination by the Deventer formula. Annual report and proceedings of COST Action 839. Immunosuppressive Vir. Dis. Poult. Pp. 170-178.

Dias, A.C., Almeida, R. and Moraes, P. 2009. Sequencing and phylogenetic analysis of the infectious bursal disease virus isolates from outbreak in layer flocks in the state of Minas Gerais. J. Vet. Sci.7: 456-485.

Eterradossi, N. 1995. Progress in the diagnosis and prophylaxis of infectious bursal disease in poultry. In Comprehensive Reports on Technical Items presented to the International Committee or to Regional Commissions. Office International des Epizooties, Paris. Pp.75-82.

Fantay, H., Balcha, E., Tesfay, A. and Afera, B. 2015. Determining Optimum Time for Administration of Live Intermediate Vaccine of Infectious Bursal Disease to Chickens at Mekelle Farm. J. Vet. Sci. Technol. 6: 223

Hasan, S., Ahmad, K., Fawad, N. and Siddique, B. 1998. A study on the infectious bursal disease around Rawalpindi, Islamabad. Pak. J. Livest. Res. 8: 84-88.

He, X., Wei, P., Yang, X., Guan, D., Wang, U.G. and Qin, A. 2012. Molecular epidemiology of infectious bursal disease viruses isolated from Southern China during the years 2000- 2010. Virus Gen. 45: 1-10.

Hitchner, S. B. 1970. Infectivity of infectious bursal disease virus for embryonating eggs. Poult. Sci. 49: 511-516.

Ismail, N.M., Saif, Y.M. and Moorhead, P.D. 1988. Lack of pathogenicity of five serotype 2 infectious bursal disease viruses in chickens. Avian Dis. 32: $757-$ 759.

Jindal, N., Mahajan, N.K., Mittal, D., Gupta, S.L. and Khokhar, R.S. 2004. Some epidemiological studies on infectious bursal disease in broiler chickens in parts of Haryana, India. Int. J. Poult. Sci. 3(7): 478-482.

Jones, B.A.H. 1986. Infectious bursal disease serology in New Zealand poultry flocks. N.Z. Vet. J. Pp. 34- 36.

Kibenge, F.S., Dhillon, A.S. and Russell, R.G. 1988. Biochemistry and immunology of infectious bursal disease virus. J. Gen. Virol. 69(8): 1757-1775.

Kouwenhoven, B. and Van den Bos, J. 1994. Control of very virulent Infectious Bursal Disease (Gumboro Disease) in the Netherlands with more virulent vaccines. In: Proceedings of the International symposium on infectious bursal disease and chicken infectious anaemia, Germany. Pp. 262-271.

Moemen, A.M., Kamal, E. S., Elzanaty, M.B. and Marwa, M.S. 2014. Genetic Characterization of Infectious Bursal Disease Viruses Associated with Gumboro Outbreaks in Commercial Broilers from Asyut Province, Egypt. Hindawi Publishing Corporation ISRN Vet. Sci. Art. ID 916412

Mohanty, G.C., Pandey, A.P. and Rajya, B.S. 1971. Infectious bursal disease in chicken. Curr. Sci. 40: 181-184.

Mor, S.K., Narang, G., Jindal, N., Mahajan, N.K., Sharma, P.C. and Rakha, N.K. 2010. Epidemiological studies on infectious bursal disease in broiler chickens in Haryana, India. Int. J. Poult. Sci. 9 (4): 395-400.

Muller, H., Islam, M.R. and Raue, R. 2003. Research on infectious bursal diseasethe past, the present and the future. Vet. Microbiol. 97: 153-165

Muller, H., Mundt, E., Eterradossi, N. and 
Islam, M.R. 2012. Current status of vaccines against infectious bursal disease. Avian. Pathol. 41: 133-199

OIE, 2012. Office of International des Epizooties. Manual of Diagnostic Tests and Vaccines for Terrestrial Animals. Infectious Bursal Disease. chap.2.3.12: $549-65$.

Pitcovski, J., Gutter, B., Gallili, G., Goldway, M., Perelman, B., Gross, G., Krispel, S., Barbakov, M. and Michael, A. 2003. Development and large-scale use of recombinant VP2 vaccine for the prevention of infectious bursal disease of chickens. J. Vaccine. 21: 4736-4743.

Sah, R.L., Kataria, J.M., Arya, S.C. and Verma, K.C. 1995. Outbreak of acute infectious bursal disease causing high mortality in chicken. Indian J. Comp. Microbiol. Immunol. Infect. Dis. 16: 713.

Tsukamoto, K., Tanimura, N., Kakita, S.I.,
Ota, K., Mase, M., Imai, K. and Hihara, H. (1995). Efficacy of three live vaccines against highly virulent infectious bursal disease virus in chickens with or without maternal antibodies. Avian Dis. Pp. 218-229.

Van den Berg, T.P. and Meulemans, G. 1991. Acute infectious bursal disease in poultry: Protection afforded by maternally derived antibodies and interference with live vaccination. Avian Pathol. 20: 409-421.

Van den Berg, T.P. 2000. Acute infectious bursal disease in poultry: a review. Avian Pathol. 29(1): 175-194.

Winterfield, R.W., Adly, A.M. and Bickford, A. 1972. Infectivity and distribution of infectious bursal disease virus in the chicken. Persistence of the virus and lesions. Avian Dis. 16: 622-632.

\section{How to cite this article:}

Pooja Kundu, G. Narang, Rajesh Chhabra, Sushma Kajal, N.K. Mahajan and Naresh Kakkar. 2017. Immune Response Study to Live Infectious Bursal Disease Vaccines in Broiler Chickens. Int.J.Curr.Microbiol.App.Sci. 6(12): 2655-2668. doi: https://doi.org/10.20546/ijcmas.2017.612.307 